\title{
Pengaruh Kompetensi, Sistem Pengendalian Internal dan Moralitas Aparatur Terhadap Kecurangan Laporan Keuangan Dalam Pengelolaan Keuangan Desa Di Kabupaten Halmahera Utara
}

\author{
PHILEP NJONJIE ${ }^{1}$, GRACE NANGOI ${ }^{2}$, HENDRIK GAMALIEL $^{3}$
}

Program Studi Magister Akuntansi Fakultas Ekonomi dan Bisnis Universitas Sam Ratulangi E-mail: njonjiephilep@gmail.com¹ ${ }^{1}$ gracebn@yahoo.com² ${ }^{2}$ hendrik_gamaliel@unsrat.ac.id ${ }^{3}$

\begin{abstract}
Financial statement fraud does not only occur in the private sector but can also occur in the government sector in form of material misstatement of financial statements with the aim of covering up the actual financial condition by conducting financial engineering. This study aims to analyze and prove empirically the influence of competencies, internal control systems, and apparatus morality on fraudulent financial statements in village financial management in North Halmahera Regency. This is a quantitative research. This study entailed primary data and data were collected by questionnaires. Respondents were village financial management apparatus staff in North Halmahera Regency. The population were 784 village apparatus in total in all villages in North Halmahera Regency. On the other hand, samples were 120 respondents. Data were analyzed ny multiple linear regression analysis and data testing was carried out with SPSS version 22 program. The results of the study show: 1). Competence influences fraudulent financial statements negatively and signifcantly in managing village finances. 2). The internal control system influences fraudulent financial statements negatively and significantly in managing village finances. 3). The morality of the apparatus influences fraudulent financial statements negatively and significantly in managing village finances. The determinant coefficient value is 0,477. This shows that the magnitude of the influence of the independent variables, namely competence, internal control system, and apparatus morality on the dependent variable, namely fraudulent financial statements explained by the model equation in this study is $47,70 \%$. While the remaining 52,30\% is explained by other factors outside of this research model.
\end{abstract}

Keywords: Competence, Internal Control System, Apparatus Morality, Fraud of Financial Statements.

\begin{abstract}
Abstrak. Kecurangan laporan keuangan (financial statement fraud) tidak hanya terjadi di sektor swasta tapi bisa juga terjadi di sektor pemerintahan dalam bentuk kesalahan penyajian material laporan keuangan dengan tujuan untuk menutupi kondisi keuangan yang sebenarnya dengan melakukan rekayasa keuangan (financial engineering). Penelitian ini bertujuan untuk menganalisis dan membuktikan secara empiris pengaruh kompetensi, sistem pengendalian internal, dan moralitas aparatur terhadap kecurangan laporan keuangan dalam pengelolaan keuangan desa di Kabupaten Halmahera Utara. Jenis penelitian ini adalah penelitian kuantitatif, dengan menggunakan data primer melalui kuesioner. Responden dalam penelitian ini adalah aparatur pengelola keuangan desa yang ada di Kabupaten Halmahera Utara. Populasi yang digunakan adalah pengelola keuangan desa sebanyak 784 aparatur desa di seluruh desa yang ada di Kabupaten Halmahera Utara sedangkan sampel yang digunakan adalah sebanyak 120 responden. Data dianalisis menggunakan analisis regresi linier berganda dan pengujian data dilakukan dengan dibantu oleh program SPSS versi 22. Hasil penelitian menunjukkan bahwa: 1). Kompetensi berpengaruh negatif dan signifikan terhadap kecurangan laporan keuangan dalam pengelolaan keuangan desa. 2). Sistem pengendalian internal berpengaruh negatif dan signifikan terhadap kecurangan laporan keuangan dalam pengelolaan keuangan desa. 3). Moralitas aparatur berpengaruh negatif dan signifikan terhadap kecurangan laporan keuangan dalam pengelolaan keuangan desa. Nilai koefisien determinan adalah 0,477. Hal ini menunjukkan bahwa besarnya pengaruh variabel independen, yaitu kompetensi, sistem pengendalian internal, dan moralitas aparatur terhadap variabel dependen yaitu kecurangan laporan keuangan yang diterangkan oleh model persamaan dalam penelitian ini adalah sebesar 47,70\%. Sedangkan sisanya sebesar 52,30\% dijelaskan oleh faktor lain diluar model penelitian ini.
\end{abstract}

Kata Kunci: Kompetensi, Sistem Pengendalian Internal, Moralitas Aparatur, Kecurangan Laporan Keuangan.

\section{Pendahuluan}

Penetapan Undang-Undang (UU) Nomor 6 tahun 2014 tentang desa diharapkan dapat membawa paradigma baru dalam pembangunan desa. Hal itu karena UU tersebut dipandang mampu mengubah cara pandang pembangunan desa bahwa kesejahteraan dan kemakmuran ekonomi tidak 
selamanya berada di perkotaan, tetapi dalam membangun Indonesia haruslah dimulai dari desa, karena desa menjadi bagian terdepan dari upaya gerakan pembangunan yang berasal dari prakarsa masyarakat, guna mencapai kesejahteraan dan kemakmuran, sekaligus berkeadilan dan berkesinambungan.

Untuk mencapai tujuan pembangunan tersebut diperlukan dana agar pembangunan desa dapat terlaksana. Salah satu sumber dana untuk membiayai pembangunan desa adalah bantuan dana desa dari pemerintah pusat. Namun, harapan lain yang tidak bisa dikesampingkan adalah dengan adanya bantuan dana desa dari pemerintah, desa dapat termotivasi untuk menjadi lebih mandiri dan kredibel sehingga mampu memenuhi kebutuhannya sendiri dan tidak semata tergantung dengan bantuan dari pemerintah, dan menjadikan bantuan dari pemerintah sebagai stimulan atau perangsang (Wardoyo, 2015).

Pengelolaan keuangan desa dilaksanakan dalam masa 1 (satu) tahun anggaran terhitung mulai tanggal 1 Januari sampai dengan 31 Desember. Kepala desa berkewajiban untuk melakukan pengelolaan keuangan desa yaitu berupa semua hak dan kewajiban desa yang dapat dinilai dengan uang serta segala sesuatu berupa uang dan barang yang berhubungan dengan pelaksanaan hak dan kewajiban desa. Hak dan kewajiban tersebut kemudian menimbulkan pendapatan, belanja, pembiayaan, dan pengelolaan keuangan desa. Dalam rangka mendukung terwujudnya tata kelola yang baik (good governance) dalam penyelenggaraan desa, pengelolaan keuangan desa dilakukan berdasarkan prinsip tata kelola yaitu transparan, akuntabel dan partisipatif serta dilakukan dengan tertib dan disiplin anggaran. Menurut Taufik (2013), dalam penganggaran partisipasi masyarakat sangat penting untuk mencegah terjadinya kebijakan-kebijakan yang menyimpang dari tujuan.

Kecurangan (fraud) menurut SA 240 IAPI (2013) adalah sebagai salah saji yang timbul dari kecurangan dalam pelaporan keuangan yaitu salah saji atau penghilangan secara sengaja jumlah atau pengungkapan dalam laporan keuangan untuk mengelabui pemakai laporan keuangan, dan salah saji yang timbul dari perlakuan tidak semestinya terhadap aktiva (seringkali disebut dengan penyalahgunaan atau penggelapan) yang berkaitan dengan pencurian aktiva entitas yang berakibat laporan keuangan tidak disajikan sesuai dengan Standar Akuntansi Keuangan yang berlaku.

Untuk mencegah terjadinya kecurangan, maka faktor kompetensi memiliki peran penting. Menurut Spencer dan Spencer (2008), kompetensi merupakan landasan dasar karakteristik seseorang dan mengindikasikan cara berperilaku, berpikir, menyamakan situasi, dan mendukung untuk periode waktu yang lama. Dengan kata lain kompetensi adalah sesuatu yang ditunjukkan seseorang dalam kerja setiap hari. Ketika aparatur sudah dibekali dengan kompetensi yang baik, maka kecurangan (fraud) yang mungkin terjadi akan dapat dicegah.

Atmadja dan Saputra (2017) menyatakan bahwa terjadinya kecurangan mengindikasikan sistem pengendalian internal dan kompetensi aparatur harus bersinergi supaya dapat melakukan pencegahan terjadinya fraud. Hal ini berarti selain adanya kompetensi aparatur, juga diperlukan adanya sistem pengendalian internal yang baik dalam pengelolaan keuangan desa.

Sistem pengendalian internal menurut Peraturan Pemerintah (PP) Nomor 60 tahun 2008 tentang Sistem Pengendalian Internal Pemerintah (SPIP) adalah proses yang integral pada tindakan dan kegiatan yang dilakukan secara terus menerus oleh pimpinan dan seluruh pegawai untuk memberikan keyakinan memadai atas tercapainya tujuan organisasi melalui kegiatan yang efektif dan efisien, keandalan pelaporan keuangan, pengamanan aset negara, dan ketaatan terhadap peraturan perundangundangan. Menurut Petrascu dan Tieanu (2014) dalam Baz et al (2017) bahwa sebuah sisitem pengendalian internal yang baik diyakini akan mampu mengurangi kemungkinan kecurangan.

Menurut Amin (2009) moralitas adalah sebuah perbuatan atau tingkah laku baik atau buruk. Moral atau tingkah laku juga akan menjadi faktor pemicu kecurangan. Kecurangan dalam suatu perusahaan atau lembaga dipengaruhi oleh para karyawan yang bekerja didalamnya. Lembaga tersebut tentu memiliki karyawan yang bekerja di masing-masing bagiannya dengan tingkat moralitas setiap individu yang beragam dan akan berpengaruh pada adanya kecenderungan kecurangan (fraud) yang mungkin timbul.

Kabupaten Halmahera Utara merupakan salah satu kabupaten yang ada di Provinsi Maluku Utara. Kabupaten Halmahera Utara memiliki jumlah desa sebanyak 196 desa. Berdasarkan data pada Dinas Pemberdayaan Masyarakat dan Desa (DPMD) Kabupaten Halmahera Utara bahwa di tahun 2017 sudah ada 10 kepala desa yang diberhentikan karena adanya dugaan kecurangan dana desa yang merugikan uang negara dalam jumlah yang sangat fantastis. Dari kasus tersebut dapat dilihat bahwa 
kepala desa maupun perangkat desa melakukan kecurangan dalam laporan keuangan dengan menyajikan laporan keuangan fiktif khususnya pada rekening belanja bidang pelaksanaan pembangunan desa, bidang pembinaan kemasyarakatan desa, dan bidang pemberdayaan masyarakat desa yang menyebabkan salah saji laporan keuangan. Association of Certified Fraud Examinations (2018) menyatakan bahwa kecurangan laporan keuangan bertujuan untuk menutupi kondisi keuangan yang sebenarnya dengan melakukan rekayasa keuangan (financial engineering).

Hal tersebut yang menjadi motivasi dalam penelitian ini, sehingga peneliti ingin meneliti variabel kompetensi, sistem pengendalian internal dan moralitas aparatur terhadap kecurangan laporan keuangan dalam pengelolaan keuangan desa di Kabupaten Halmahera Utara.

Tujuan dari penelitian ini adalah untuk menganalisis dan membuktikan secara empiris:

1. Pengaruh kompetensi terhadap kecurangan laporan keuangan dalam pengelolaan keuangan desa di Kabupaten Halmahera Utara.

2. Pengaruh sistem pengendalian internal terhadap kecurangan laporan keuangan dalam pengelolaan keuangan desa di Kabupaten Halmahera Utara.

3. Pengaruh moralitas aparatur terhadap kecurangan laporan keuangan dalam pengelolaan keuangan desa di Kabupaten Halmahera Utara.

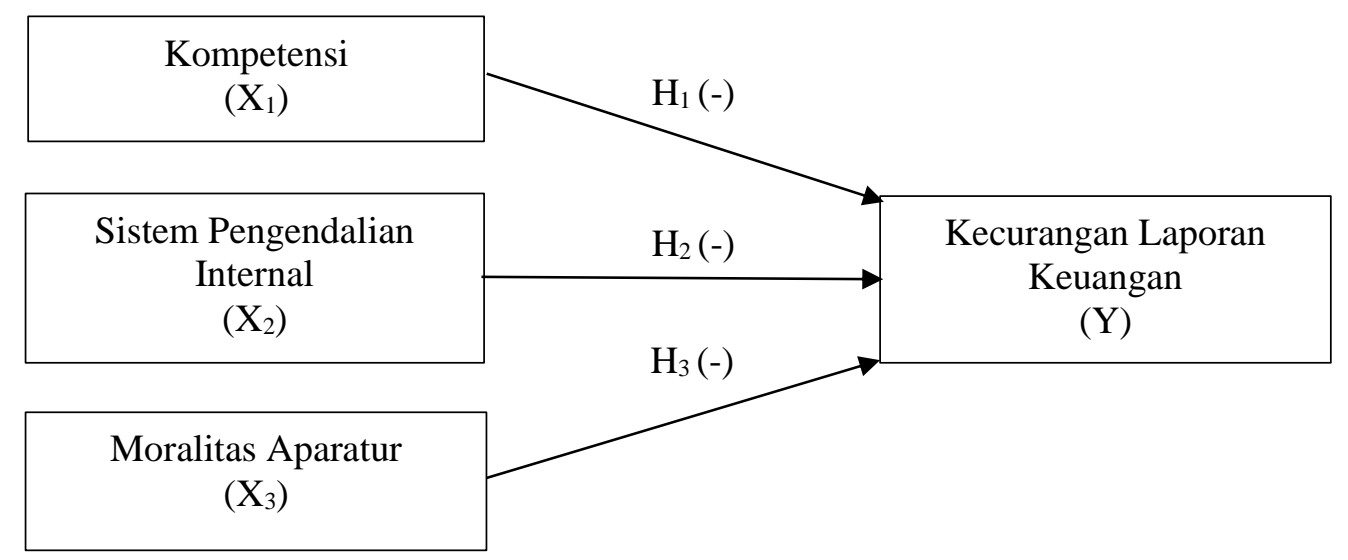

Gambar 1. Kerangka Konseptual

Menurut Marwansyah (2012), kompetensi adalah perpaduan pengetahuan, keterampilan, sikap, dan karakteristik pribadi lainnya yang diperlukan untuk mencapai keberhasilan dalam sebuah pekerjaan, yang bisa diukur dengan menggunakan standar yang telah disepakati, dan yang dapat ditingkatkan melalui pelatihan dan pengembangan. Kompetensi meliputi aspek intent (niat), action (tindakan), dan outcome (hasil).

Atmadja (2017) mengatakan bahwa kompetensi aparatur memiliki peran penting dalam pengelolaan keuangan desa untuk mencapai tujuan bersama yaitu meningkatkan kesejahteraan masyarakat melalui perbaikan ekonomi desa, sosial, budaya dan bidang lainnya, terlebih aparatur nantinya akan diawasi dan bersentuhan langsung dengan badan pengawas keuangan yang independen yang ditunjuk pemerintah pusat untuk mengawasi penggunaan dana desa serta mempertanggungjawabkan. Wirakusuma dan Setiawan (2019) menyatakan bahwa kompetensi berpengaruh negatif terhadap kecenderungan kecurangan akuntansi. Hal ini menunjukkan bahwa semakin tinggi kompetensi seseorang menyebabkan semakin rendah tindakan kecenderungan kecurangan akuntansi.

Sistem pengendalian internal menurut Peraturan Pemerintah (PP) Nomor 60 tahun 2008 tentang Sistem Pengendalian Internal Pemerintah (SPIP) adalah proses yang integral pada tindakan dan kegiatan yang dilakukan secara terus menerus oleh pimpinan dan seluruh pegawai untuk memberikan keyakinan memadai atas tercapainya tujuan organisasi melalui kegiatan yang efektif dan efisien, keandalan pelaporan keuangan, pengamanan aset negara, dan ketaatan terhadap peraturan perundangundangan.

Indriastuti (2017) yang menyatakan bahwa semakin efektif pengendalian internal dalam suatu instansi, maka semakin rendah kemungkinan terjadinya kecurangan dalam instansi tersebut. Jadi, 
semakin efektif tingkat pengendalian internal dalam suatu sistem birokrasi pemerintah desa, maka akan semakin kecil pula kesempatan bagi pengelola keuangan desa untuk melakukan kecurangan laporan keuangan.

Menurut Amin (2009) moralitas adalah sebuah perbuatan atau tingkah laku baik atau buruk. Moral atau tingkah laku juga akan menjadi faktor pemicu kecurangan. Kecurangan dalam suatu perusahaan atau lembaga dipengaruhi oleh para karyawan yang bekerja.

Aliyudin (2015) menyatakan bahwa moralitas individu berpengaruh negatif terhadap kecurangan. Artinya dengan memiliki moral yang baik dalam bekerja berarti pegawai juga memiliki dedikasi yang tinggi terhadap instansi. Dengan demikian, pegawai akan cenderung bekerja dengan baik untuk kemajuan instansi tersebut. Sebaliknya, jika memiliki moral rendah, maka pegawai cenderung akan bekerja kurang baik, dan akan merasionalisasikan hal tersebut sebagai hal yang wajar dikarenakan kurangnya kepedulian akan baik buruknya hasil pekerjaan yang dilakukan, sehingga ketika pegawai tersebut melakukan kecurangan, akan dianggap sebagai hal yang biasa.

\section{Metode Penelitian}

Jenis penelitian ini adalah penelitian kuantitatif yang berbentuk asosiatif menggunakan data primer dengan tujuan untuk menguji hipotesa tentang pengaruh kompetensi, sistem pengendalian internal dan moralitas aparatur terhadap kecurangan laporan keuangan dalam pengelolaan keuangan desa. Teknik analisis yang digunakan dalam penelitian ini adalah analisis regresi linier berganda.

Populasi dari penelitian ini adalah aparat pengelola keuangan desa di Kabupaten Halmahera Utara yang berjumlah 196 desa, terdiri atas kepala desa, sekretaris desa, bendahara, dan unsur kepala urusan (kaur), sehingga total populasi berjumlah 784. Jumlah sampel dalam penelitian ini sebanyak 120 responden diperoleh dari jumlah 30 desa dikalikan dengan 4 orang pengelola keuangan desa. Metode pengambilan sampel dalam penelitian ini adalah dengan cara purposive sampling.

\section{Hasil dan Pembahasan}

Data penelitian ini adalah data primer yang bersumber dari hasil pengisian kuesioner oleh para responden, yakni aparat pengelola keuangan desa di Kabupaten Halmahera Utara. Peneliti mengantarkan langsung kuesioner kepada responden untuk mengantisipasi terjadinya respond rate yang rendah pada saat pengembalian kuesioner.

Uji validitas digunakan untuk mengetahui kelayakan butir-butir dalam suatu daftar pertanyaan dalam mendefinisikan suatu variabel. Daftar pertanyaan ini pada umumnya mendukung suatu kelompok tertentu. Uji validitas dilakukan untuk setiap butir pertanyaan. Hasil $r_{\text {hitung }}$ dibandingkan dengan $r_{\text {tabel }}$ dimana $\mathrm{df}=\mathrm{n}-2$ dengan sig 5\%. Jika $\mathrm{r}_{\text {tabel }}<\mathrm{r}_{\text {hitung }}$ maka valid (Sujarweni, 2016:239). Dalam penelitian ini, $\mathrm{r}_{\text {tabel }}$ dengan menggunakan $\mathrm{df}=118$ (diperoleh dari sampel 120 dikurangi 2) dan tingkat signifikansi $5 \%$ adalah sebesar 0,151 . Hasil uji validasi menunjukkan bahwa semua item pertanyaan untuk variabel kompetensi, sistem pengendalian internal, moralitas paratur dan kecurangan laporan keuangan memiliki kriteria valid karena masing-masing item pertanyaan mempunyai nilai $\mathrm{r}_{\text {tabel }}<\mathrm{r}_{\text {hitung. }}$.

Reliabilitas (keandalan) merupakan ukuran suatu kestabilan dan konsistensi responden dalam menjawab hal yang berkaitan dengan kontruk-kontruk pertanyaan yang merupakan dimensi suatu variabel dan disusun dalam suatu bentuk kuesioner. Uji reliabilitas dapat dilakukan secara bersamasama terhadap seluruh butir pertanyaan. Jika nilai Alpha > 0,70 maka reliabel (Sujarweni, 2016:239). Hasil uji reliabilitas menunjukkan bahwa nilai Cronbach's Alpha untuk kompetensi sebesar 0,956, sistem pengendalian internal sebesar 0,959, moralitas aparatur sebesar 0,949, dan kecurangan laporan keuangan sebesar 0,826. Dengan demikian seluruh item pertanyaan yang digunakan untuk mengukur masing-masing variabel dalam penelitian ini dinyatakan reliabel. Hal ini terlihat dari nilai Cronbach's Alpha masing-masing variabel lebih dari 0,70 .

Uji normalitas bertujuan untuk mengetahui distribusi data dalam variabel yang digunakan dalam penelitian. Jika probabilitas > 0,05 maka data penelitian berdistribusi normal, dan apabila probabilitas < 0,05 maka data penelitian dianggap tidak berdistribusi normal (Sujarweni, 2016:72). Hasil uji normalitas menggunakan uji Kolmogorov-smirnov menunjukkan bahwa koefisien Kolmogorov-Smirnov sebesar 0,068 dengan tingkat signifikansi sebesar 0,200. Nilai signifikansi ini 
lebih besar dari $\alpha 0,05(0,200>0,05)$. Hal ini menunjukkan bahwa data dalam variabel penelitian ini terdistribusi secara normal.

Uji multikolinearitas menurut Sujarweni (2016:230) diperlukan untuk mengetahui ada tidaknya variabel independen yang memiliki kemiripan antar variabel independen dalam suatu model. Kemiripan antar variabel independen akan mengakibatkan korelasi yang sangat kuat. Uji VIF (Varians Inflation Factor) yang dihasilkan antara 1 - 10 maka tidak terjadi multkolinieritas. Hasil uji multikolinieritas diketahui pada nilai Tolerance tidak ada variabel independen yang memiliki nilai kurang dari 0,1 dan tidak ada tidak ada variabel independen memiliki nilai VIF lebih dari 10, yaitu nilai VIF untuk variabel kompetensi $\left(\mathrm{X}_{1}\right)$ sebesar $1,350<10$ dan nilai tolerance $0,741>0,1$; nilai VIF untuk variabel sistem pengendalian internal $\left(\mathrm{X}_{2}\right)$ sebesar $1,450<10$ dan nilai tolerance $0,690>0,1$; nilai VIF untuk variabel moralitas aparatur $\left(\mathrm{X}_{3}\right)$ sebesar $1,326<10$ dan nilai tolerance $0,754>0,1$. Jadi dapat disimpulkan bahwa data dalam penelitian ini terbebas dari masalah multikolinieritas.

Uji heteroskedastisitas diperlukan untuk menguji apakah persamaan regresi berganda terjadi kesamaan atau ketidaksamaan varian residual dari observasi yang satu dengan observasi yang lain. Persamaan regresi yang baik jika tidak terjadi heteroskedastisitas. Uji heteroskedastisitas dapat menggunakan uji Glesjer. Jika probabilitas signifikansi masing-masing variabel independen > 0,05, maka dapat disimpulkan tidak terjadi heteroskedastisitas dalam model regresi (Sujarweni, 206:238). Uji heteroskedastisitas menghasilkan nilai signifikansi masing-masing variabel lebih besar dari 0,05, yaitu kompetensi sebesar 0,813, sistem pengendalian internal sebesar 0,774, dan moralitas aparatur sebesar 0,067. Sehingga dapat disimpulkan bahwa model regresi tidak mengandung adanya heteroskedastisitas.

Model regresi berganda dalam penelitian ini adalah untuk menguji pengaruh Kompetensi $\left(\mathrm{X}_{1}\right)$, Sistem Pengendalian Internal $\left(X_{2}\right)$, dan Moralitas Aparatur $\left(X_{3}\right)$ terhadap Kecurangan Laporan Keuangan (Y). Hasil analisis regresi berganda adalah sebagai berikut:

Tabel 1.

Hasil Analisis Regresi Berganda

\begin{tabular}{|ll|c|c|}
\hline \multirow{2}{*}{ Model } & \multicolumn{2}{c|}{ Unstandardized Coefficients } \\
\cline { 2 - 4 } & B & Std. Error \\
\hline 1 & (Constant) & 7,399 & 0,365 \\
& Kompetensi $\left(\mathrm{X}_{1}\right)$ & $-0,427$ & 0,045 \\
Sistem Pengendalian Internal $\left(\mathrm{X}_{2}\right)$ & $-0,346$ & 0,046 \\
\multicolumn{1}{|l|}{ Moralitas Aparatur $\left(\mathrm{X}_{3}\right)$} & $-0,103$ & 0,045 \\
\hline
\end{tabular}

Persamaan regresi berganda adalah sebagai berikut:

$\mathrm{Y}=\alpha+\beta 1 \mathrm{X}_{1}+\beta 2 \mathrm{X}_{2}+\beta 3 \mathrm{X}_{3}+e$

$\mathrm{Y}=\mathbf{7 , 3 9 9}-\mathbf{0 , 4 2 7} \mathrm{X}_{1}-0,346 \mathrm{X}_{2}-0,103 \mathrm{X}_{3}+e$

Persamaan tersebut menunjukkan bahwa koefisien dari semua variabel bebas menunjukkan angka negatif, hal ini berarti bahwa hubungan antara kompetensi, sistem pengendalian internal, dan moralitas aparatur terhadap kecurangan laporan keuangan adalah berlawanan arah. Atau dengan kata lain bahwa jika semakin rendah kompetensi, sistem pengendalian internal, dan moralitas aparatur maka semakin tinggi kecurangan laporan keuangan dalam pengelolaan keuangan desa di Kabupaten Halmahera Utara. Begitu pula sebaliknya, jika semakin tinggi kompetensi, sistem pengendalian internal, dan moralitas aparatur maka semakin rendah kecurangan laporan keuangan dalam pengelolaan keuangan desa di Kabupaten Halmahera Utara.

Untuk mengetahui ada tidaknya pengaruh masing-masing variabel independen terhadap variabel dependen, dapat dilakukan dengan membandingkan $p$-value pada kolom t dengan tingkat signifikansi yang digunakan sebesar 5\% (Sujarweni, 2016:113). Hasil uji t pada output SPSS dapat dilihat pada Tabel berikut: 
Tabel 2.

Hasil Uji Hipotesis

\begin{tabular}{|c|c|c|c|c|c|}
\hline \multirow[t]{2}{*}{ Model } & \multicolumn{2}{|c|}{$\begin{array}{l}\text { Unstandardized } \\
\text { Coefficients }\end{array}$} & $\begin{array}{c}\text { Standardized } \\
\text { Coefficients }\end{array}$ & \multirow[t]{2}{*}{$\mathrm{t}$} & \multirow[t]{2}{*}{ Sig. } \\
\hline & B & Std. Error & Beta & & \\
\hline 1 (Constant) & 7.399 & 0,365 & & 20,270 & 0,000 \\
\hline Kompetensi $\left(\mathrm{X}_{1}\right)$ & $-0,427$ & 0,045 & $-0,736$ & $-9,559$ & 0,000 \\
\hline $\begin{array}{l}\text { Sistem Pengendalian Internal } \\
\left(\mathrm{X}_{2}\right)\end{array}$ & $-0,346$ & 0,046 & $-0,602$ & $-7,541$ & 0,000 \\
\hline Moralitas Aparatur $\left(\mathrm{X}_{3}\right)$ & $-0,103$ & 0,045 & $-0,174$ & $-2,274$ & 0,025 \\
\hline
\end{tabular}

Nilai $t_{\text {hitung }}$ dari kompetensi $\left(\mathrm{X}_{1}\right)$ adalah negatif 9,559 sehingga $t_{\text {hitung }}>t_{\text {tabel }}(9,559>1,981)$. Signifikansi dari variabel kompetensi $\left(\mathrm{X}_{1}\right)$ adalah sebesar 0,000 artinya $p$-value $<0,05$. Hal ini menunjukkan bahwa $\mathrm{H}_{\mathrm{a} 1}$ diterima dan $\mathrm{H}_{01}$ ditolak, terbukti bahwa kompetensi $\left(\mathrm{X}_{1}\right)$ berpengaruh negatif dan signifikan terhadap kecurangan laporan keuangan (Y). Nilai thitung dari sistem pengendalian internal $\left(X_{2}\right)$ adalah negatif 7,541 sehingga $t_{\text {hitung }}>t_{\text {tabel }}(7,541>1,981)$. Signifikansi dari variabel sistem pengendalian internal $\left(\mathrm{X}_{2}\right)$ adalah 0,000 artinya $p$-value $<0,05$. Hal ini menunjukkan bahwa $\mathrm{H}_{\mathrm{a} 2}$ diterima dan $\mathrm{H}_{02}$ ditolak, terbukti bahwa sistem pengendalian internal $\left(\mathrm{X}_{2}\right)$ berpengaruh negatif dan signifikan terhadap kecurangan laporan keuangan (Y). Nilai $t_{\text {hitung dari }}$ moralitas aparatur $\left(\mathrm{X}_{3}\right)$ adalah negatif 2,274 sehingga $t_{\text {hitung }}>t_{\text {tabel }}(2,274>1,981)$. Signifikansi dari variabel moralitas aparatur $\left(\mathrm{X}_{3}\right)$ adalah 0,025 artinya $p$-value $<0,05$. Hal ini menunjukkan bahwa $\mathrm{H}_{\mathrm{a} 3}$ diterima dan $\mathrm{H}_{03}$ ditolak, terbukti bahwa moralitas aparatur $\left(\mathrm{X}_{3}\right)$ berpengaruh negatif dan signifikan terhadap kecurangan laporan keuangan (Y).

Nilai koefisien determinasi atau adjust $\mathrm{R}^{2}$ adalah sebesar 0,477 atau $47,70 \%$. Angka tersebut berarti sebesar $47,70 \%$ Kecurangan Laporan Keuangan dalam pengelolaan keuangan desa di Kabupaten Halmahera Utara dapat dijelaskan oleh variabel Kompetensi $\left(\mathrm{X}_{1}\right)$, Sistem Pengendalian Internal $\left(\mathrm{X}_{2}\right)$, dan Moralitas Aparatur $\left(\mathrm{X}_{3}\right)$. Sedangkan sisanya $(100 \%-47,70 \%=52,30 \%)$ disebabkan oleh faktor-faktor lain diluar pengujian ini. Koefisien korelasi (R) sebesar 0,700 menunjukkan bahwa hubungan (korelasi) antara variabel independen dengan variabel dependen merupakan hubungan yang kuat. Artinya Kompetensi $\left(\mathrm{X}_{1}\right)$, Sistem Pengendalian Internal $\left(\mathrm{X}_{2}\right)$, dan Moralitas Aparatur $\left(\mathrm{X}_{3}\right)$ terhadap Kecurangan Laporan Keuangan mempunyai hubungan yang kuat.

\section{Pengaruh Kompetensi Terhadap Kecurangan Laporan Keuangan}

Hasil pengujian hipotesis pertama $\left(\mathrm{H}_{1}\right)$ terkait pengaruh kompetensi terhadap kecurangan laporan keuangan menunjukkan bahwa kompetensi berpengaruh negatif terhadap kecurangan laporan keuangan dalam pengelolaan keuangan desa di Kabupaten Halmahera Utara. Dengan demikian hipotesis 1 terdukung karena secara empirik terbukti.

Hasil pengujian ini selaras dengan konsep kompetensi Spencer dan Spencer. Menurut Spencer dan Spencer (2008), kompetensi aparatur perlu dipertimbangkan dalam sistem pencegahan fraud. Kompetensi merupakan landasan karakteristik seseorang dan mengindikasikan cara berperilaku, berpikir, menyamakan situasi, dan mendukung untuk periode waktu yang lama. Dengan kata lain, kompetensi adalah sesuatu yang ditunjukkan seseorang dalam kerja setiap hari. Ketika aparatur sudah dibekali dengan kompetensi yang baik, maka kecurangan (fraud) yang mungkin akan terjadi dapat dicegah.

Hasil pengujian ini selaras dengan penelitian sebelumnya yang dilakukan oleh Wirakusuma dan Setiawan (2019) yang menyatakan bahwa kompetensi berpengaruh negatif terhadap kecenderungan kecurangan akuntansi. Hal ini menunjukkan bahwa semakin tinggi kompetensi seseorang menyebabkan semakin rendah tindakan kecenderungan kecurangan akuntansi. Hasil penelitian ini juga selaras dengan penelitian Nurul et al (2018), Fazini dan Suparno (2019) yang menyatakan bahwa kompetensi sumber daya manusia berpengaruh negatif terhadap kecenderungan terjadinya kecurangan. Artinya semakin rendah kompetensi sumber daya manusia dalam mengelola keuangan desa, maka akan semakin tinggi tingkat kecenderungan terjadinya kecurangan dalam pengelolaan keuangan desa. 


\section{Pengaruh Sistem Pengendalian Internal Terhadap Kecurangan Laporan Keuangan}

Hasil pengujian hipotesis kedua $\left(\mathrm{H}_{2}\right)$ terkait pengaruh sistem pengendalian internal terhadap kecurangan laporan keuangan menunjukkan bahwa sistem pengendalian internal berpengaruh negatif terhadap kecurangan laporan keuangan dalam pengelolaan keuangan desa di Kabupaten Halmahera Utara. Dengan demikian hipotesis 2 terdukung karena secara empirik terbukti.

Hasil pengujian ini selaras dengan konsep fraud triangle Cressey (1953). Salah satu faktor terjadinya kecurangan menurut Cressey (1953) adalah opportunity (kesempatan). Kesempatan yaitu kondisi atau situasi yang memungkinkan seseorang melakukan atau menutupi tindakan tidak jujur. Biasanya hal ini dapat terjadi karena adanya internal control yang lemah, kurangnya pengawasan, dan/atau penyalahgunaan wewenang. Menurut Zimbelman et al (2014), cara yang paling umum untuk mencegah kecurangan adalah dengan memiliki sistem pengendalian yang baik. Artinya sistem pengendalian internal yang baik merupakan satu-satunya alat yang paling efektif dalam mencegah dan mendeteksi kecurangan. Hal ini menunjukkan bahwa organisasi dengan sistem pengendalian internal yang baik dapat mengurangi tejadinya kecurangan (fraud).

Hasil pengujian ini sesuai dengan penelitian sebelumnya yang dilakukan oleh Indriastuti (2017) yang menyatakan bahwa semakin efektif pengendalian internal dalam suatu instansi, maka semakin rendah kemungkinan terjadinya kecurangan dalam instansi tersebut. Hal yang senada juga dinyatakan dalam hasil penelitian Irphani (2017), Coram et al (2006), Rae dan Subramaniam (2008), Putri (2014), Ansori (2017), dan Rahima et al (2018) bahwa sistem pengendalian internal organisasi yang efektif dapat mengurangi kecenderungan individu untuk melakukan tindakan kecurangan.

\section{Pengaruh Moralitas Aparatur Terhadap Kecurangan Laporan Keuangan}

Hasil pengujian hipotesis ketiga $\left(\mathrm{H}_{3}\right)$ terkait pengaruh moralitas aparatur terhadap kecurangan laporan keuangan menunjukkan bahwa moralitas aparatur berpengaruh negatif terhadap kecurangan laporan keuangan dalam pengelolaan keuangan desa di Kabupaten Halmahera Utara. Dengan demikian hipotesis 3 terdukung karena secara empirik terbukti.

Hasil pengujian ini selaras dengan konsep level penalaran moral Kohlberg (1969). Dalam teori level penalaran moral Kohlberg (1969) disebutkan bahwa pengetahuan akan penalaran moral ini dapat digunakan untuk mengetahui kecenderungan individu melakukan suatu tindakan tertentu, terutama yang terkait dengan dilema etika, berdasarkan hasil penalaran moralnya. Kohlberg (1969) menekankan pentingnya perhatian kepada kesadaran moral ini untuk memahami bagaimana keputusan etis diambil dan juga alasan etis mengapa seseorang mengambil keputusan tertentu. Moralitas merupakan faktor penting dalam timbulnya kecurangan. Kecenderungan kecurangan (fraud) juga dipengaruhi oleh moralitas orang yang terlibat didalamnya. Dalam suatu perusahaan atau instansi moralitas manajemen sangat berpengaruh terhadap kecenderungan kecurangan (fraud) yang mungkin timbul dalam perusahaan.

Menurut Amin (2009) moralitas adalah sebuah perbuatan atau tingkah laku baik atau buruk. Moral atau tingkah laku juga akan menjadi faktor pemicu kecurangan. Kecurangan dalam suatu perusahaan atau lembaga dipengaruhi oleh para karyawan yang bekerja didalamnya. Lembaga tersebut tentu memiliki karyawan yang bekerja di masing-masing bagiannya dengan tingkat moralitas setiap individu yang beragam dan akan berpengaruh pada adanya kecenderungan kecurangan (fraud) yang mungkin timbul.

Hasil pengujian ini sesuai dengan penelitian sebelumnya tentang pengaruh moralitas terhadap kecurangan laporan keuangan antara lain penelitian dari Aliyudin (2015), Junia et al (2016), Lahaya (2017), Korompis et al (2018), serta Widjajanti dan Wahyuni (2019) yang menyatakan bahwa moralitas individu berpengaruh negatif terhadap kecurangan. Artinya dengan memiliki moral yang baik dalam bekerja berarti pegawai juga memiliki dedikasi yang tinggi terhadap instansi. Dengan demikian, pegawai akan cenderung bekerja dengan baik untuk kemajuan instansi tersebut. Sebaliknya, jika memiliki moral rendah, maka pegawai cenderung akan bekerja kurang baik, dan akan merasionalisasikan hal tersebut sebagai hal yang wajar dikarenakan kurangnya kepedulian akan baik buruknya hasil pekerjaan yang dilakukan, sehingga ketika pegawai tersebut melakukan kecurangan, akan dianggap sebagai hal yang biasa. 


\section{Kesimpulan dan Saran}

Berdasarkan hasil penelitian dan pembahasan dapat disimpulkan bahwa:

1. Kompetensi berpengaruh negatif terhadap kecurangan laporan keuangan dalam pengelolaan keuangan desa di Kabupaten Halmahera Utara. Artinya semakin kompeten aparat pengelola keuangan desa, maka semakin berkurang kecurangan laporan keuangan dalam pengelolaan keuangan desa.

2. Sistem pengendalian internal berpengaruh negatif terhadap kecurangan laporan keuangan dalam pengelolaan keuangan desa di Kabupaten Halmahera Utara. Artinya semakin efektif sistem pengendalian internal yang diterapkan, maka semakin rendah kecurangan laporan keuangan yang akan terjadi.

3. Moralitas aparatur berpengaruh negatif terhadap kecurangan laporan keuangan dalam pengelolaan keuangan desa di Kabupaten Halmahera Utara. Artinya semakin tinggi level penalaran moral aparatur pengelola keuangan desa, maka semakin ia akan menghindarkan diri dari tindakan melakukan kecurangan.

4. Kompetensi aparatur berpengaruh terhadap kecurangan laporan keuangan dalam pengelolaan keuangan desa. Hal ini karena kemampuan aparatur desa memiliki peran penting dalam pengelolaan keuangan desa untuk mencapai tujuan bersama. Sistem pengendalian internal berpengaruh terhadap kecurangan laporan keuangan dalam pengelolaan keuangan desa. Hal ini dikarenakan bahwa segala jenis tindakan kecurangan dalam keuangan di suatu organisasi dapat dicegah melalui sistem pengendalian internal yang memadai. Namun kompetensi yang baik dan sistem pengendalian yang memadai harus didukung dengan moralitas aparatur yang baik pula. Hal ini karena kompetensi atau kemampuan seseorang dalam mengelola keuangan sering disalahgunakan untuk melakukan kecurangan.

Adapun saran yang dapat diberikan berdasarkan hasil penelitian yang telah dilakukan adalah sebagai berikut:

1. Saran bagi pemerintah daerah Kabupaten Halmahera Utara :

a) Kompetensi sangat penting dalam mencegah terjadinya kecurangan laporan keuangan, oleh karena itu perlu adanya peningkatan kompetensi bagi aparat pengelola keuangan desa. Peningkatan kompetensi bisa dilakukan dengan memberikan pelatihan-pelatihan dan menempatkan pegawai dengan latar belakang pendidikan yang sesuai dengan bidangnya.

b) Sistem pengendalian internal sangat penting dalam mencegah terjadinya kecurangan laporan keuangan, oleh karena itu perlu peningkatan sistem pengawasan dan pengendalian internal oleh inspektorat kabupaten sebagai Aparat Pengawas Internal Pemerintah untuk menjamin bahwa sistem pengendalian internal dapat berjalan dengan baik. Selain itu, inspektorat juga dapat bertindak sebagai problem solver bagi desa-desa sehingga apabila desa mendapatkan masalah ataupun kendala dalam pengelolaan keuangan, inspektorat dapat membantunya sehingga kecurangan laporan keuangan dapat dicegah.

c) Moralitas aparatur sangat penting dalam mencegah terjadinya kecurangan laporan keuangan, oleh karena itu perlu membentuk kesadaran moral aparatur pengelola keuangan desa yang berorientasi kepada nilai moral universal. Pembentukan kesadaran moral aparatur pengelola keuangan desa dapat dilakukan dengan melibatkan tokoh-tokoh agama dan tokoh-tokoh adat untuk memberikan pemahaman tentang nilai-nilai moral yang baik.

2. Saran bagi peneliti selanjutnya, agar memperdalam hasil temuan penelitian ini dengan menambah variabel-variabel yang menyebabkan terjadinya kecurangan laporan keuangan.

\section{Daftar Pustaka}

Ansori, A. F. 2017. Pengaruh Implementasi Good University Governance, Keefektifan Sistem Pengendalian Internal dan Ketaatan Aturan Akuntansi Terhadap Kecenderungan Fraud Pada PTKIN-BLU. Tesis Magister Ilmu Akuntansi Universitas Lampung.

Aliyudin, R. S. 2015. Pengaruh Moralitas Individu dan Pengendalian Internal Terhadap Kecenderungan Kecurangan Akuntansi. Doctoral dissertation, Tesis Program Magister Akuntansi Universitas Widyatama.

Amin, Widjaja. 2009. Kecurangan Laporan Keuangan (Financial Statement Fraud), Jakarta: PT. Indeks. 
Association of Certified Fraud Examiners (ACFE). 2018. Report to the Nations on Occupational Fraud and Abuse.

Atmadja, A. T., dan Saputra, A. K. 2017. Pencegahan Fraud dalam Pengelolaan Keuangan Desa. Jurnal Ilmiah Akuntansi dan Bisnis, 7-16.

Baz, R., Samsudin, R. S., and Che-Ahmad, A. 2017. The Role of Internal Control and Information Sharing in Preventing Fraud in the Saudi Banks.

Coram, P., Ferguson, C., dan Moroney, R. 2006. The value of internal audit in fraud detection. Journal of Accounting and Finance, 48(4), 543-59.

Cressey, D. R. 1953. Other People's Money. Montclair, NJ: Patterson Smith, 1-300.

Fazini, H. N., dan Suparno, S. 2019. Pengaruh Sumber Daya Manusia dan Pengendalian Internal Terhadap Kecurangan Akuntansi Studi Pada PT. Pegadaian (Persero) di Kota Banda Aceh. Jurnal Ilmiah Mahasiswa Ekonomi Akuntansi, 3(4), 625-637.

Institut Akuntan Publik Indonesia. 2013. Standar Audit (SA 240) Tanggung Jawab Auditor Terkait Dengan Kecurangan Dalam Suatu Audit Atas Laporan Keuangan.

Indriastuti, D. E. 2017. Analisis Pengaruh Asimetri Informasi, Pengendalian Internal, Persepsi Kesesuaian Kompensasi, Moralitas Individu, dan Ketaatan Aturan Akuntansi Terhadap Kecurangan Akuntansi. InFestasi, 12(2), 115-130.

Irphani, A. 2017. Pengaruh Tekanan, Keefektifan Sistem Pengendalian Internal, Perilaku Tidak Etis, dan Jabatan dalam Pengelola Keuangan Terhadap Fraud (Studi pada Satuan Kerja Perangkat Daerah Kota Metro) (Doctoral dissertation, Tesis. Magister Ilmu Akuntansi, Fakultas Ekonomi dan Bisnis, Universitas Lampung).

Junia, N., Rasuli, M., dan Diyanto, V. 2016. Pengaruh Moralitas Aparat, Kesesuaian Kompensasi, dan Ketaatan Aturan Akuntansi terhadap Kecenderungan Kecurangan Akuntansi (Studi Empiris pada Satuan Kerja Perangkat Daerah Kabupaten Kampar). Jurnal Online Mahasiswa Fakultas Ekonomi Universitas Riau, 3(1), 1623-1637.

Kohlberg, L. 1969. Stage and sequence: The cognitive-development approach moral action to socialization. In D. A. Goslin (Ed). Handbook of socialization theory and research. Chicago: RandMcNally.

Korompis, S. N., Saerang, D. P., dan Morasa, J. 2018. Pengaruh Moralitas Individu, Asimetri Informasi, dan Keefektifan Pengendalian Internal Terhadap Kecenderungan Kecurangan (Fraud) Berdasarkan Persepsi Pada Badan Pengelola Keuangan dan Barang Milik Daerah Provinsi Sulawesi Utara. Jurnal Riset Akuntansi dan Auditing "Goodwill”, 9 (1).

Lahaya, I. A. 2017. Pengaruh Moralitas Individu dan Pengendalian Internal Terhadap Kecenderungan Kecurangan Akuntansi (Studi Eksperimen Pada Mahasiswa Jurusan Akuntansi Fakultas Ekonomi Universitas Mulawarman Samarinda. Jurnal Ekonomika: Manajemen, Akuntansi, dan Perbankan Syari'ah, 4(1), 20-45.

Marwansyah. 2012. Manajemen Sumber Daya Manusia. Yogyakarta: Andi.

Nurul, A., Prayudi, M. A., Diatmika, I. P. G., AK, S., dan Si, M. 2018. Pengaruh Perspektif Fraud Diamond Terhadap Kecenderungan Terjadinya Kecurangan (Fraud) Dalam Pengelolaan Keuangan Desa. JIMAT (Jurnal Ilmiah Mahasiswa Akuntansi) Undiksha, 8(2).

Peraturan Pemerintah Republik Indonesia Nomor 60 Tahun 2008 Tentang Sistem Pengendalian Internal Pemerintah (SPIP).

Putri, A. A. P. A. 2014. Pengaruh Keefektifan Pengendalian Internal dan Kepuasan Kerja terhadap Kecenderungan Kecurangan Akuntansi pada Dinas Pendapatan Pengelolaan Keuangan Aset Daerah Istimewa Yogyakarta. Nominal, Barometer Riset Akuntansi dan Manajemen, 3(1).

Rae, K., dan Subramaniam, N. 2008. Quality of internal control procedures: Antecedents and moderating effect on organisational justice and employee fraud. Managerial Auditing Journal, 23(2), 104-124.

Rahimah, L. N., Murni, Y., dan Lysandra, S. 2018. Pengaruh Penyajian Laporan Keuangan Desa, Lingkungan Pengendalian, dan Moralitas Individu Terhadap Pencegahan Fraud Yang Terjadi Dalam Pengelolaan Alokasi Dana Desa (Studi Kasus di Desa Sukamantri, Desa Sukamanah, Desa Sukaresmi dan Desa Gunungjaya Kecamatan Cisaat Kabupaten Sukabumi). Jurnal Ilmiah Ilmu Ekonomi (Jurnal Akuntansi, Pajak dan Manajemen), 6(12), 139-154.

Spencer, L. M., dan Spencer, P. S. M. 2008. Competence at Work models for superior performance. John Wiley and Sons. 
Sujarweni, V. Wiratna. 2016. Kupas Tuntas Penelitian Akuntansi dengan SPSS. Yogyakarta: Pustaka Baru Press.

Taufik, T. 2013. Pengelolaan Keuangan Desa Dalam Sistem Keuangan Negara Republik Indonesia. Jurnal Ekonomi, 17(1).

Wardoyo, Hasto. 2015. Penguatan Pengelolaan Keuangan Desa dan Optimalisasi Peran BUMDesa Sebuah Upaya Menuju Desa Mandiri dan Kredibel di Kabupaten Kulon Progo. Seminar Nasional Temu Forum Dosen Akuntansi Sektor Publik 2015, Universitas Atma Jaya Yogyakarta.

Widjajanti, A., dan Wahyuni, W. 2019. Pengaruh Moralitas Aparat dan Asimetri Informasi Terhadap Kecenderungan Kecurangan Akuntansi (Studi Empiris Pemerintah Kota Surabaya). Liability, 1(1), 43-62.

Wirakusuma, I. G. B., dan Setiawan, P. E. 2019. Pengaruh Pengendalian Internal, Kompetensi dan Locus of Control Pada Kecenderungan Kecurangan Akuntansi (Studi Kasus Pada Dinas Pendapatan Daerah Kota Denpasar). E-Jurnal Akuntansi, 1545-1569.

Zimbelman, M. F., Albrecht, C. C., Albrecht, W. S., dan Albrecht, C. D. 2014. Akuntansi Forensik Edisi 4, Forensic Accounting Fourth Edition. Salemba Empat Jakarta. 